\title{
DETECTION OF MYCOFLORA AND MYCOTOXIN IN RAW PEANUT ARACHIS HYPOGEA L. KERNELS IN BANGLADESH
}

\author{
Md Maniruzzman Khandaker*, Tasmilur Rahman, Md Matiur Rahim ${ }^{1}$ and \\ Md TARIQUl Hassan ${ }^{1}$
}

Department of Botany, Jagannath University, Dhaka-1100, Bangladesh

Keywords: Peanut, Mycoflora, Mycotoxin.

\begin{abstract}
Raw peanut kernel samples were collected from 13 areas of Bangladesh for determination of mycoflora and mycotoxin. Fungi associated with the tested samples throughout the investigation were Aspergillus flavus, A. niger, Aspergillus sp. (1), Aspergillus sp. (2), Penicillium sp., Fusarium sp., Rhizopus sp. and Curvularia sp. A. flavus was the most common fungus followed by A. niger. Colonies of fungi were found to form 79.81 to $98.10 \%$ of raw peanut kernels. Out of the 13 samples, eight were found to be contaminated with 11.91 to $182.6 \mathrm{ppb}$ of total aflatoxins and five samples were free from aflatoxins.
\end{abstract}

The peanut (Arachis hypogaea L.) belonging legume family, Fabaceae is one of the major oilseed crops of the world. Peanuts can be consumed as raw, roasted or mixed with other foods or in different processed forms. Recently, peanuts have gained much attention as functional food because it has high protein and energy values and it is suitable for producing other food products. Peanuts contain all the essential amino acids necessary for normal body growth and metabolism. A major challenge in peanut production is fungal contamination. Mycoflora means the fungi characteristic of a particular habitat or environment. Mycotoxins are secondary metabolites produced by microscopic filamentous fungi, which can develop on food crops (Milicevic et al. 2010). Mycotoxin attracts worldwide attention because of the significant economic losses associated with their impact on human health, animal productivity and trade (Wagacha and Muthomi 2008). Mycotoxins are mainly produced by fungal species belonging to the genera Aspergillus, Penicillium and Fusarium which are ubiquitous in the environment (Klich 2007). The type and level of mycotoxin production result from the interactions of fungi, host and the environment (Pitt 2000). It has been estimated that 25\% of crops produced worldwide are contaminated each year with unacceptable levels of mycotoxins during food production, processing, transport and storage (Kamika and Takoy 2011). Aflatoxins are a group of mycotoxins which are chemically similar to toxic fungal metabolites produced by certain moulds of the genus Aspergillus growing on a number of raw food commodities. Aflatoxins are now known to be mainly produced by Aspergillus flavus, A. parasiticus and A. nomius (Do and Choi 2007). There are about 20 known aflatoxins but only four of them (aflatoxins B1, B2, G1 and G2) are widely studied because of their toxic effects. Aflatoxin B1 is the most pernicious of these toxins (Wangikar et al. 2005). Aflatoxins are more prevalent in tropical and sub-tropical areas where environmental conditions, namely high temperature and humidity prevail, which favour the growth of fungi and production of mycotoxins on the crops. Peanut seeds are good substrate for growth and subsequent aflatoxin production by aflatoxigenic fungi (Xue et al. 2003). In Bangladesh peanut is very popular and is consumed by all walks of people. But its mycolfora and mycotoxin levels are still unknown. So the present experiment was conducted to find out the mycoflora association of peanuts and determination of mycotoxin level in raw peanut kernels which are used in many forms of peanut products.

*Author for correspondence: <maniruzzamanbot@gmail.com>. ${ }^{1}$ IFST, BCSIR, Dhaka, Bangladesh. 
Raw peanut were collected from 13 different locations i.e. Thataribazar, Mirpur, Rampura, Rangpur, Jamalpur, Santinagar, Munshigonj, Faridpur, Joypurhat, Dinajpur, Tangail, Gazipur and Narayangonj during January to May, 2016 for the detection of peanut born fungi and its mycotoxins. The collected samples were thoroughly mixed and divided into two units where one unit of $300 \mathrm{~g}$ from each sample was tested for mycoflora using two International Seed Testing Authority (ISTA) recognized media, PDA and blotter. Another unit was tested for mycotoxin detection. Each of $300 \mathrm{~g}$ samples for detection of mycoflora were divided into two parts. One part was tested in blotter and another part was in PDA media. For the detection of mycoflora the raw peanut kernels were surface sterilized by sodium hypochloride $(\mathrm{NaOCl})$ and rinsed thrice in sterile distilled water and then air dried. The air dried peanut kernels were kept in three layered sterilized blotting paper in Petri dishes (90 mm dia.) soaked with sterilized water at the rate of 6 seeds per plate. The plates were incubated at room temperature $\left(20-23^{0} \mathrm{C}\right)$ for four days. The incubated plates were examined for determination of mycoflora and their frequencies. Same number of kernels were plated in PDA. Mycotoxin level of peanut kernels samples were analyzed by standard HPLC (High Performance Liquid Chromatography, Model No. Agilent: 1100 series) method of Food Toxicology Research Section of IFST BCSIR, Dhaka which is validated according to the EC decision 2002/657/EC.

HPLC condition

a. Mobile phase $=$ Acetonitrile: Methanol: Water $=22.5: 22.5: 55$

b. Column: C-18,25 cm × $4.6 \mathrm{~mm}(10 \mu \mathrm{m}$ packing).

c. Flow rate: $1.5 \mathrm{ml} / \mathrm{min}$.

d. Column temperature: $30^{\circ} \mathrm{C}$.

e. Injection volume: $20 \mu \mathrm{l}$.

f. Excitation wavelength: $365 \mathrm{~nm}$.

g. Emission wavelength: $418 \mathrm{~nm}$.

h. Software: Agilent Chem Station for 3D systems. Rev. A. 02.

Table 1. Per cent of fungal colonies formed by different genera in 13 peanut samples.

\begin{tabular}{|c|c|c|c|c|c|c|c|c|c|c|}
\hline \multirow{2}{*}{$\begin{array}{c}\text { Sample } \\
\text { No. }\end{array}$} & \multirow[t]{2}{*}{ Area } & \multicolumn{8}{|c|}{$\%$ of colony formed by fungal genera } & \multirow[t]{2}{*}{ Total } \\
\hline & & A.F. & A.N. & A1 & A2 & Pen & $\mathrm{Fu}$ & $\mathrm{Rz}$ & Cur & \\
\hline 1 & Thataribazar & 50.05 & 24.43 & 15.09 & - & 5.76 & 3.58 & 1.09 & - & 100 \\
\hline 2 & Mirpur & 43.32 & 37.82 & - & 10.36 & 3.94 & 2.28 & 1.97 & 0.31 & 100 \\
\hline 3 & Rampura & 35.16 & 37.76 & - & 22.58 & 1 & 2.8 & 0.7 & - & 100 \\
\hline 4 & Rangpur & 44.67 & 38.3 & 9.18 & - & 2.79 & 4.52 & 0.27 & 0.27 & 100 \\
\hline 5 & Jamalpur & 30.96 & 38.77 & 26.7 & - & - & 1.38 & 2.19 & - & 100 \\
\hline 6 & Santinagar & 32.51 & 19.20 & 41.97 & - & 0.83 & - & 5.08 & 0.41 & 100 \\
\hline 7 & Munshiganj & 35.35 & 48.26 & 9.65 & - & 0.81 & 3.14 & 2.21 & 0.58 & 100 \\
\hline 8 & Faridpur & 39.24 & 57.14 & - & - & 1.72 & 0.86 & 1.04 & - & 100 \\
\hline 9 & Joypurhat & 51.20 & 40.29 & - & - & - & 2.41 & 6.1 & - & 100 \\
\hline 10 & Dinajpur & 43.97 & 32.76 & - & - & 1.72 & 14.65 & 6.9 & - & 100 \\
\hline 11 & Tangail & 43.36 & 35.92 & 6.16 & - & 0.96 & 4.04 & 9.03 & 0.53 & 100 \\
\hline 12 & Gazipur & 54.57 & 35.35 & - & - & - & 6.32 & 3.76 & - & 100 \\
\hline 13 & Narayangonj & 49.44 & 40.58 & - & - & 0.4 & 6.55 & 3.03 & - & 100 \\
\hline Total (\%) & & 43.56 & 37.25 & 7.53 & 2.73 & 1.45 & 3.96 & 3.37 & 0.15 & 100 \\
\hline
\end{tabular}

A.F. = Aspergillus flavus, A.N. = Aspergillus niger, A1 = Aspergillus sp. (1), A2 = Aspergillus sp. (2), Pen = Penicillium sp., $\mathrm{Fu}=$ Fusarium sp., $\mathrm{Rz}=$ Rhizopus sp. and Cur $=$ Curvularia sp. 
Clolonies of Aspergillus flavus, A. niger and Rhizopus sp. were commonly observed in all the 13 samples followed by Fuzarium sp. in 12 samples, Penicillium sp. in 10 samples, Aspergillus sp. 1, and Curvularia in 6 samples and Aspergillus sp. (2) in 3 samples. A. flavus was most occurred fungal species which was $43.56 \%$ of the total colonies followed by A. niger (37.25\%). Curvularia sp. was the least occurred fungal flora with $0.15 \%$ (Table 1 ).

Fungal colonies formed in PDA ranged from 47.67 to $56.90 \%$ while it was 43.10 to $52.33 \%$ in blotters. Most of raw kernels were infected and fungal colonies were formed from 79.81 to $98.1 \%$ of the kernels and only 1.99 to $20.19 \%$ kernels were uninfected. Sample 3 was most infected and sample 9 was least infected kernels (Table 2).

Table 2. Per cent of fungal colony formation in kernels of 13 peanut samples on PDA and blotter media and per cent of kernel infection.

\begin{tabular}{clcccc}
\hline \multirow{2}{*}{$\begin{array}{c}\text { Sample } \\
\text { No. }\end{array}$} & Area & \multicolumn{2}{c}{ \% colony formation } & \multicolumn{2}{c}{ \% infected/uninfected kernels } \\
\cline { 3 - 6 } & & on PDA & on Blotter & Infected & Uninfected \\
\hline 1 & Thatari bazar & 55.81 & 44.19 & 96.27 & 3.73 \\
2 & Mirpur & 51.30 & 48.70 & 97.3 & 2.7 \\
3 & Rampura & 51.45 & 48.55 & 98.1 & 1.99 \\
4 & Rangpur & 54.03 & 45.97 & 90.23 & 9.77 \\
5 & Jamalpur & 52.70 & 47.30 & 89.72 & 10.28 \\
6 & Santinagar & 54.87 & 45.13 & 90 & 10 \\
7 & Munshiganj & 47.67 & 52.33 & 91.76 & 8.24 \\
8 & Faridpur & 50.00 & 50.00 & 79.81 & 20.19 \\
9 & Joypurhat & 49.28 & 50.72 & 95.32 & 4.68 \\
10 & Dinajpur & 56.90 & 43.10 & 85.5 & 14.5 \\
11 & Tangail & 48.78 & 51.22 & 93.64 & 6.36 \\
12 & Gazipur & 48.68 & 51.32 & 95.15 & 4.85 \\
13 & Narayangonj & 49.92 & 50.08 & 97.78 & 2.22 \\
\hline
\end{tabular}

All of the 13 peanut samples were tested for aflatoxin detection. Various amounts of aflatoxin were detected from eight samples viz. 1, 2, 3, 6, 7, 8, 11 and 13. The highest $182.62 \mathrm{ppb}$ of total aflatoxins were detected in sample 1 which includes aflatoxin $\mathrm{B} 1=5.82 \mathrm{ppb}, \mathrm{B} 2=0.15 \mathrm{ppb}, \mathrm{G} 1=$ $176.16 \mathrm{ppb}$ and G2 $=0.49 \mathrm{ppb}$. The second highest total aflatoxin $62.91 \mathrm{ppb}$ were detected in sample 13 where, aflatoxin B1 $=5.32 \mathrm{ppb}, \mathrm{B} 2=0.08 \mathrm{ppb}, \mathrm{G} 1=57.19 \mathrm{ppb}$ and G2 $=0.32 \mathrm{ppb}$, it was followed by sample 3, where $62.89 \mathrm{ppb}$ of total aflatoxins were detected, which were included aflatoxin B1 $=4.91 \mathrm{ppb}, \mathrm{G} 1=57.70 \mathrm{ppb}$, aflatoxin G2 $=0.28 \mathrm{ppb}$, and aflatoxin B2 was not detected in this sample. All the eight aflatoxins detected peanut samples exceeded the European Union permissible limit for total aflatoxin. European Union permissible limit for total aflatoxinis is four ppb (Commission Regulation No. 165/2010). Aflatoxins were not detected from the remaining five samples viz. sample 4, 5, 9, 10 and 12 (Table 3).

Mycoflora association was detected in peanut seed samples from five different Governorates in Egypt, namely Aswan, Giza, Behera, Monofya and Sharkia. The fungi isolated from the samples belong to four fungal genera i.e. Aspergillus, Fusarium, Penicillium and Rhizopus. Agar plate (PDA) medium was an enhanced method for seed health testing than the blotter test method 
Table 3. Aflatoxin analysis result of thirteen raw peanut samples.

\begin{tabular}{|c|c|c|c|c|c|c|}
\hline \multirow{2}{*}{$\begin{array}{c}\text { Sample } \\
\text { no. }\end{array}$} & \multirow{2}{*}{$\begin{array}{l}\text { Collection } \\
\text { area }\end{array}$} & \multicolumn{4}{|c|}{ Aflatoxins (ppb) } & \multirow{2}{*}{$\begin{array}{l}\text { Total amount of } \\
\text { aflatoxins (ppb) }\end{array}$} \\
\hline & & B1 & B2 & G1 & G2 & \\
\hline 1 & Thataribazar & 5.82 & 0.15 & 176.16 & 0.49 & 182.62 \\
\hline 2 & Mirpur & 3.73 & - & 6.51 & 1.67 & 11.91 \\
\hline 3 & Rampura & 4.91 & - & 57.70 & 0.28 & 62.89 \\
\hline 4 & Rangpur & - & - & - & - & - \\
\hline 5 & Jamalpur & - & - & - & - & - \\
\hline 6 & Santinagar & 3.64 & - & 9.31 & - & 12.95 \\
\hline 7 & Munshiganj & 4.26 & - & 12.05 & - & 16.31 \\
\hline 8 & Faridpur & 12.03 & 2.87 & 7.35 & - & 22.25 \\
\hline 9 & Joypurhat & - & - & - & - & - \\
\hline 10 & Dinajpur & - & - & - & - & - \\
\hline 11 & Tangail & 1.89 & - & 40.31 & - & 42.20 \\
\hline 12 & Gazipur & - & - & - & - & - \\
\hline 13 & Narayangonj & 5.32 & 0.08 & 57.19 & 0.32 & 62.91 \\
\hline
\end{tabular}

and gave higher numbers of fungal colony (Embaby and Mona 2006, Embaby et al. 2008). Similar results and techniques were observed from this investigation of raw peanut samples. Oliveira et al. (2009) observed in their experiment that $44.2 \%$ of 240 peanut samples analyzed were positive for aflatoxin at levels between 0.5 and $103.8 \mu \mathrm{g} / \mathrm{kg}$. In the present study, out of 13 raw peanut samples eight samples (61.54\%) were contaminated with various amounts (11.91 - $182.62 \mathrm{ppb})$ of aflatoxins, which corroborate the above finding.

\section{Acknowledgements}

The authors acknowledge the financial support of Ministry of Science and Technology, Govt. of People's Republic of Bangladesh to carry out the research.

\section{References}

Do JH and Choi D 2007. Aflatoxins: detection, toxicity, and biosynthesis. Biotechnology and Bioprocess Engineering 12: 583-593.

EmbabyEM and Mona MAG 2006. Seed borne fungi and mycotoxins associated with some legume seeds in Egypt. Journal of Applied Sciences Research 2(11): 1064-1071.

Embaby EM, Swelium MA, Hazaa MM, Abdel whhab MA and El Shahat EA 2008. Effect of Aquilegia vulgaris L. (Columbine) extract on Aspergillus flavus contaminated corn grains (Zea maize L.) in Egypt. Egyptian J. of App. Sciences 23(9): 62-73.

European Commission 2010. Commission Regulation (EU) No 165/2010 amending Regulation (EC) No 1881/2006 setting maximum levels for certain contaminants in foodstuffs as regards aflatoxins.

Kamika I and Takoy LL 2011. Natural occurrence of aflatoxin B1 in peanut collected from Kinshasa, Democratic Republic of Congo. Food Control 22(11): 1760-1764.

Klich MA 2007. Aspergillus flavus: The major producer of aflatoxin. Molecular Plant Pathology 8(6): 713722. 
Milicevic DR, Skrinjar M and Baltic T 2010. Real and perceived risks for mycotoxins contamination in foods and feeds: Challenges for food safety control. Toxins 2: 572-592.

Oliveira CAF, Goncalves NB, Rosim RE and Fernandes AM 2009. Determination of aflatoxins in peanut products in the northeast region of Sao Paulo, Brazil. International Journal of Molecular Sciences. 10(1): 174-183.

Pitt JI 2000. Toxigenic fungi and mycotoxins. British Medical Bulletin 56(1): 184-192.

Wagacha JM and Muthomi JW 2008. Mycotoxin problem in Africa: Current status, implications to food safety and health and possible management strategies. International Journal of Food Microbiology 124: $1-12$.

Wangikar PB, Dwivedi P, Sinha N, Sharma AK and Telang AG 2005. Teratogenic effects in rabbits of simultaneous exposure to ochratoxin A and aflatoxin B1 with special reference to microscopic effects. Toxicology 215: 37-47.

Xue HQ, Isleib TG, GA Payne, Wilson RF and Novitzky WP 2003. Comparison of aflatoxin production in normal and lug-oleic backcross-derived peanut lines. Plant Dis. 87:1360-1365.

(Manuscript received on 24 February, 2018; revised on 13 July, 2018) 